Original Article

Received/Accepted

Dates

25.09.2021/10.29.2021

$\mathrm{DOI}$

10.52096/usbd.5.23.5.11
Uluslararası Sosyal Bilimler Dergisi

www.sobider.net

ISSN: 2548-0685

\title{
Yeni Medya Teknolojilerinin Kullanılmasının Siyasal İletişime Getirdiği Yenilikler
}

Umut Yildiz

\author{
Millî Eğitim Bakanlığı Eğitim Yöneticisi \\ umutyildiz80@hotmail.com \\ ORCID:0000-0001-2352-3199
}

\section{Özet}

Enformasyon ve bilgi topluluğuyla eş zamanlı olarak medeniyet tarihinin gelişimsel evresinde sıçrayışsal etki biçimde kabul gören dijital devrim öncesi, iletişim araç ve gereçleriyle biçimlendirilen dijital devrime göndermede bulunulan çağımızda her husus gibi siyasî iletişimsellik anlayışı da başkalaşmaktadır.

Radyonun ve televizyonun iletişim dünyasındaki bireylerin siyasî ilişki biçimlerinde merkezî konuma yükseldiği bu süreç içerisinde alıcılar, vericiler ve kanallar arasındaki sınıflandırmada bulunan hususlardan kanallar, radyo ve televizyonla birlikte diğer kitle iletişim araç ve gereçleri kendisine ait nitelikleri ölçüsünde giderek gelişmiş ve kalıcılık göstermiştir.

Günümüz kitle iletişim araç ve gereçlerine dayalı siyasî iletişimsellik anlayışının belirlediği mahdut çerçeve içerisinde gerçekleşmekte olan bu süreç özelinde muhataplardan her biri rol, istek, beklenti, kimlik, meşrutiyet, uzlaşımsal yönleri ve ilkeleriyle birbiriyle çatışma durumuna gelmiş ve kitlesel iletişimin araçsallık niteliğine göre kurgulanma zorunda kalmıştır. İlerleyen süreç içerisinde dijital devrim ile belirlenmiş olan çerçeve özelinde yeni medya araç ve gereçleri siyasî iletişimsellik anlayışı anlayışının esas perspektifini belirlemiştir. Bu süreçse yeni medya anlayışının birçok sahada olduğu gibi siyasî iletişimsellik anlayışı sahasında da belirleyici bir unsur şeklinde ortaya çıkma olgusunu beraberinde getirmiştir.

Anahtar Sözcükler: Teknoloji, Siyasal İletişim, Yeni Medya.

\section{Innovations in Political Communication by the Use of New Media Technologies}

\begin{abstract}
The new media, which is under the traditional media, is rapidly becoming an extremely important channel for political communication. In our digital age, which refers to the electronic revolution shaped by means of communication, before the electronic revolution, which is accepted as a leap in the developmental line
\end{abstract}


of the history of civilization as synonymous with the information and knowledge community, political communication also changes like every other issue.

Radio and television have risen to a central position in the political relations of people in the electronic world; In this process, channels, radio and television, which are among the 3 issues in the classification between receivers, transmitters and channels, have made the way of using and benefiting from both transmitters and receivers into a habit, in accordance with their own characteristics.

In this process, which took place within the boundaries drawn by television-mediated political communication, each of the parties had to construct roles, wishes, expectations, identity, constitutionalism, reconciliation, activities according to the instrumentality of television. By internalizing the drawn framework and borders more and more every day, it has indexed all kinds of political activities that can be realized through the media in daily life to radio and television, and then to new media tools.

Key Words: Technology, Political Communication, New Media.

\section{Giriş}

Mikro ve makro ölçekte basitlikten karmaşığa yönelen adımlar özelinde var oluşsallığını ortaya koyan siyasî kurumlar; iletişim anlayışı süreciyle gerekli bir aradalık içerisinde yüz yıllardır toplumsallığa ilişkin arkaplanı önemli ölçekte biçimlendirmektedir. İletişimselliğin ve siyasî anlayışın siyasî iletişimsellik anlayışı çerçevesinde birliktelikleri bilimsel alakalılık sahası olmasının yanı sıra kuram manasında kendisine has çerçevesini günbegün daha fazda belirginleştirmek suretiyle belirler iken, temelde siyasî hayat düşüncesinin ana oyuncusu olan kişiler olmak üzere, bir biçimde siyasî kurumlarla çerçevelenmiş tüm bireyler yönünden varlıklı ve çeşitli uygulama imkanları ortaya koymaktadır (Bakan, 2007).

En hafif ifadesiyle, ideoloji amaçlarını, topluluktaki bazı gurup, kitle, ulus ya da bloklara kabullendirme ve gerektiğindeyse fiile dönüştürme, uygulama sahasına koyma bakımından siyasî kişilerce değişik iletişim teknik ve yönteminin kullanılmasıyla gerçekleştirilen iletim (Aziz, 2003) şeklinde kavramsallaştırılabilen siyasî iletişimsellik anlayışının bir vetire şekilinde ortaya konması, söz konusu süreç içerisinde yeni medyayla ya da internetle ilişkiliselliğini de uzanım anlamında değerlendirilmektedir.

Siyasî iletişimsellik anlayışının, siyasî kişilerce gerçekleştirilen siyasî tesirliğin kamusallaşmasıyla alakalı yönü bizatihi tabiatı gereğince medyanın kural ve kaidesine tabiî iken, siyasî iletişimsellik anlayışının direkt medyayla ilişkisellik içersinde bulunmayan yönü mevcut koşullar altında önemli 
ölçekte medyada vardır ve geçerliliği süren iletişimsel ilke ve yöntemlerin fikrî zemini içerisinde sürdürülmektedir (Tuncel, 2005).

Medyadan ayrık düşünülmeyecek hususun ne tür bir biçimde iş birliği yürüttüğünün anlaşılabilmesi amacıyla medya özeliklerine göre altsınıflara ayırılması gereksinimi bulunmaktadır. İletişim ve yeni medya teknik ve yöntemi hususunda gerçekleştirilen araştırma ve incelemelere yönelik değerlendirilme yapılırsa bir çok incelemede medya unsurunun geleneksel ve yeni medya olarak 2 ana ölçekte kabul gördüğü daha iyi anlaşılacaktır. İletişim teknolojisi ifadesiyle radyoyla başlamış olan, televizyonla süregelen ve ilerleyen bir devre atıf yapılır iken, internetse bir bütün halinde dijital iletişim teknolojileri olarak kavramsallaştırılmıştır.

\section{Siyasal İletişimde Yeni Medya Teknolojilerinin Kullanılması}

\section{Siyasal İletişimin İlişkili Olduğu Alanlar}

Kökleri eski 2 bilim dalına yaslanan, yalnızca pratik sahada genç olarak isimlendirilebilecek tarihî döneme haiz olan siyasî iletişimsellik anlayışı, gerek pratikte uygulanma yönünden, gerekse de teorideki ilişkisellik yönünden epeyce uzamsal bir ağa haizdir. Özelikle iletişimin bir bilim olarak kattığı değerlerle iç içe olan yapısı siyasî iletişimsellik anlayışının da çerçevesinin genişlemesini ve ilişkide olduğu sahaların birden fazda bulunmasını beraberinde getirmiştir (Uztuğ, 2004).

Siyasî iletişimsellik anlayışının bir disiplin şeklinde kabullenilmesinde en mühim etmen, hiç kuşku yok ki siyasî anlayışın bilimselleşmesiyle alakalı ilerlemeler, gelişmeler ve değişimdir. Yöneten ve yönetilenlerin, toplulukları inandırabilmesi, ikna edebilmesi amacıyla tutumlarının ve davranımlarının açıklanma, sorgulanma, müspet ve menfi taraflarının sergilenme, hepsinden mühimi, topluluklar üzerinde tesirli olabilmeleri amacıyla siyasî kavrayışın ve onun başaktörü olan siyasetçinin de mercek altında bulundurulmasını gerektirmiştir (Aziz, 2003).

Siyaset bilimi ve siyasî iletişimsellik anlayışı, geniş kaplama haiz olmasından mütevellit uzamsal manada ve geniş sahada bir çok bilimdalıyla yakın ilişkisellik içersindedir. Siyasî iletişimsellik anlayışıysa; adalet, siyaset, antropoloji, ekonomi, tarih, psikoloji, sosyoloji, sağlık coğrafya v.s. gibi sosyal bilimlerin, kısaca marketing, reklâm, endokrin, halk ile ilişkileri gibi iletişimin yakından alakadar olduğu bilim dallarıyla ilişkisellik dahilindedir (Devran, 2004). 


\section{Siyasal İletişim ve Siyasal Propaganda}

Propaganda ifadesinin ilk kez kullanılışı 1636'da Katoliklik Roma Kilisesi'nce meydana getirilen Congraegatio de Propaganida Fidel'e dayandırılmaktadır. Protestanlık Kilisesi'nin meydana çıkmaya başladığı zamana rastlayan bu devirde Katoliklik Kiliseleri, öğretilerine karşıt geleni propaganda yolu ile itikada çağırmayı amaçlamaktaydı (İnal ve Karabacak, 1997).

Propaganda ifadesi kavram olarak on sekizinci yüz yılda tümel kullanıma gelinceye dek hep kilisece kullanılageldi. Siyasal propaganda tam manası manası ile Fransız Devriminden sonrasında başlamıştır. 1. Dünya Savaşı'nın esnasında propaganda etkinliği kamu oyunu mühim ölçekte meşgûl etmiş ve 1 Dünya Savaşı'nı müteakip senelerde propaganda teknik ve yöntemi ile alakalı araştırılara yönelik ilgi sürat ile artarak küresel ölçekteki savaşları içerisinde yer alan değişik siyasî akımlarca fazlası ile kullanıla gelmiştir (Devran, 2004).

Propaganda, 2. Dünya Savaşı'nın önce ve sonrasında, aynı anda savaş sırasında da Almanlarca iletişim teknolojisinden faydalanılmak sebebiyle kesif biçimde kullanıla gelmiştir. Almanlar propaganda unsuruna çokça ehemmiyet vermiş olduğu için Propaganda Bakanlığı namıyla kuruluşa yer verilmiş ve liderliğine de J. Gobbeels’i getirmiştir (Bektaş, 1996).

Propagandanın mutlak bir ereği yoktur. Bu ereği kitleye kabul ettirmek istemekte. Bundan ötürü de evvelden seçilmiş, ayıklanmış bilgileri sunmaktadır. En tesirli, en kalıcı olacağına inandığı, araştırılarla geliştirdiği simgeleri kullanmakta. Dolaysıyla, ereğine ters düşecek, dikkatleri dağıtabilecek gerçekliklerdense hiç söz etmemekte (Özerkan ve İnceoğlu, 1997).

Propagandanın en mühim unsurunu kamu oyu oluşturmakta. Yetkeli ve totaliter rejimde yöneten kişiler üzerinde bulundurduğu tüm araç ve gereçleri kamu oyunu tek yönde oluşturabilmek için kullanır iken, özgür rejimde kamu oyu çok perspektifli tesirler zemininde, baskı ve dayatmalardan uzak bir biçimde oluşmakta (Öztürk, 2008).

Propagandanın siyasî iletişimsellik anlayışı sahasıyla alakasına baktığımızda, iki saha içerisinde sıkıca bir ilişkisellik olduğunu rahatça görebiliriz. Vakit vakit siyasî iletişimsellik anlayışının propaganda şeklinde ifade edildiği durumları da görülebilir. Propaganda, lügat manasıyla, mesajların tek yönlü ve kesif bir biçimde hedeflenen kitleye aktarılması şeklinde ifade edilebilir. Propaganda mefhumunda, verilen mesajların tartışılma, yorumlanılma durumu değil de, verildiği biçimde ve mündemiçte kabulü, onamı, tutumların ve davranımların değiştirilmesi beklenir. Burada iletişimsellikten fazda, tek yönlüce mesaj gönderimi, kısaca iletimi söz konusudur. 
İletilerin içeriğini tartışma imkanı yoktur. Propagandada süreler de çok kısadır; verilmesi istenilen mesaj ve içerikler kısa süre içerisinde verilerek neticeye ulaşılmak istenir (Üste, 2000).

$\mathrm{Bu}$ ifadeler paralelinde propagandayı tek yönlüce bir mesaj kesifliği, bir mefhum aldatılması şeklinde kavramlandırmak imkan dahilindedir. Amaçsa ne olursa olsun hedef kitleyi şahsî yönden inanç ve eyleme yöneltmektir. Besleyici tepkiselliğin gelebileceği tüm yolları tıkamak bahasına bunu da yapma esastır (Aktaş, 2004).

Bir takım hususlarda propagandada ifade şeklini bulmuş olan teknik ve yöntemler siyasî iletişimsellik anlayışındakilerle benzeşmeler göstermekte. Mesela, kaynağın güvenilir bulunulması kaygıları, kitleyi mesajları almaya hazır hâle getirme çabaları, çoğunluktan söz etme, sayılar yerine ağırşak rakamlar verme, vazıh müsşerek hususlardan hareket etme, mesajı yineleme, kitlelere ulaşma amacıyla iletişimsellik araç ve gereçlerini kullanma gibi özelikler siyasî iletişimsellik anlayışında da kullanılmaktadır (Öztürk, 2008).

\section{Siyasal İletişim ve Siyasal Halkla İlişkiler}

Siyasî iletişimsellik anlayışı ve siyasal halk ile ilişkilerin fazda müşterek tanımı bulunmaktadır ve buna bağlı birbirini etkileyen mühim müşterek özeliklere sahiplerdir. Bu müssterek özelikler siyasetle halk ile ilişkilerin tek bir çatı altında toplanmasına imkan sağlamakta ve siyasal halk ile ilişkiler mefhumunu meydana çıkarmıştır. Yalnızca önce halk ile ilişkiler ifadesini bir kaç değişik tanımla dillendirmek ve siyasetçi gözünden halk ile ilişkiler bağıntısını oluşturma suretiyle siyasal halk ile ilişkiler ifadesine ulaşmakta faydalar vardır (Habermas, 1997).

Halk ile ilişkiler, özel ve tüzel kişilerin belirtilmiş kitleler ile dürüstçe bağlantılar kurup geliştirerek bunları müspet inanç ve eyleme yöneltmesi, tepkisellikleri değerlendirmek suretiyle tutumuna yön vermesi, böylelikle karşılıklılık esasına dayalı yararlar sağlayan ilişkileri devam ettirmek üzere planlı çaba ve gayretleri kaplayan bir yönetici sanatıdır (Aktaş, 2004).

Halk ile ilişkiler, örgüt ve kamuyu içerisinde karşllıklı iletişimselliği, anlayışı kabulü ve iş birliğini kurmak ve sürdürmeye yardım eden bir yönetim tarzıdır. Problem yönetimini kaplamaktadır. Yönetim anlayışını, kamu oyundan haberdar olmayı ve kamu oyuna karşı sorumluluk duygusuyla davranmayı sürdürmesi, sosyal değişimleri izlenmesine yardımcı olmaktadır. Bu değişmeleri tesirli biçimde kullanmak suretiyle, topluluksal eğilim ve yönelimleri ön görmede, ilk uyarıcı 
sistem olmak hizmeti görmektedir. Başlıca araç ve gereçler şeklinde, manalı iletişimsellik anlayışını ve araştırma türlerini kullanmaktadır (Wolton, 1991).

Siyasetçi kişiler yönünden halk ile ilişkiler denildiğindeyse, devlet-hükümet organı, idareler, mahkemeleri, emniyetin teşkilatı, ordunun yönetimi ve sosyal güvenlikle ilgili kuruluşlarıyla birlikte seçmen, aile, aşiret, sendika, kulüp ve dernek gibi organlar akla gelmektedir. Tüm bu resmî ve mülkî kurumların arasındaki ilişkiselliğin kurulumu siyasî kurumun başarılı olmasının esasını meydana getirmektedir. Şurası unutulmamalı ki, siyasî yaşamda müspet ve menfî imajlar halk ile ilişkilerdeki etkililik neticesini meydana getirmektedir (Özerkan ve İnceoğlu, 1997).

$\mathrm{Bu}$ yaklaşımlar halk ile ilişkiselliklerin misyonunu anlatırken siyasî mekanizmalarla olan ilişkisinden de ip uçları elde etmemizi sağlamaktadır. İnsanî durum, sarih biçimde meydana getirilen yönlendirilme ve eğilimlere yönelik direnim iç güdüsü gösterme meyyalindedir. $\mathrm{Bu}$ hakikat siyasetçi kişileri reklâmın dışında, daha nesnel ve çekimser gözükerek bireyin kandırılmak korkularından doğan direnimlerini kıran başka yöntemlere baş vurmaya itmiş̧ir. Bu yöntem ve tekniklerden en esaslısı da siyasal halk ile ilişkiler şeklinde meydana çıkmıştır (Oskay, 1992).

Siyasî adayların kimliklerinin yapılandırılması ile çelişik haber ve duyumların yayılmamasına itina gösterilmek suretiyle medyanın alakasını celp edecek, haber niteliği arz eden olguların yaratılması da halk ile ilişkiler uzmanlarının vazifelerinden birisini meydana getirmektedir. Söz konusu vazife, siyasî kampanya ve gösterimleri meydana getiren iklimi, heyecanla tartışma ortamları, düzmece durumları ve diğerlerini, adayların avantaj durumunu arttıracak biçimde gerçekleştirmesini sağlamak suretiyle, denetlenmesini içermektedir (Uztuğ, 2004).

Yirminci yüz yılın ortalarında Amerika Birleşik Devletlerinde meydana gelen siyasal halk ile ilişkiler ifadesinin günbegün genişleyen ölçeğinde, sayılı medya yönetimleri şeklinde; imaj yönetimleri, bilgi yönetimleri, kurum iç yönetimleri gibi faaliyetlerin bulunduğunu söyleyebiliriz (Wolton, 1991).

\section{Siyasal İletişim ve Siyasal Reklâm}

Siyasî iletişimsellik anlayışı çabalamalarının reklâm sahasıyla olan birlikteliği epeyce köklüdür. Siyasî iletişimsellik anlayışının gelişimsellik sürecindeki ilk çabalamalarda siyasal reklâm uygulamalarına sıkça baş vurulduğunu görmekteyiz. Dolaysıyla siyasî iletişimsellik anlayışıyla 
reklâm içersinde geçmişteki devre yaslanan ve gelecekte de devam edecek sıkı bir ortaklık söz konusudur (Uztuğ, 2004).

Çağımızda tümleşik marketing iletişiminin bileşeninden birisi pozisyonunda bulunan reklâmda; ses, resim, söz, görüntü ve simge forumundaki mesajlar, oluşması hedef edinilen bir tesiri meydana getirmek amacıyla kitlelere değiş̧ik kanallar yolu ile iletilir. Reklâmın iletişim yönünden en sarih özeliği, oluşturulması hedef edinilen tesirlerin genellik ile esas kitleyi harekete geçirmek amacında olmasıdır (Özkan, 2004).

Reklâm, çağımızda insanlık hayatını biçimlendirmekte olan ve yansıtan en mühim sosyal etkileşimlerden birisi olarak; her yerde, her kesin zorunluluk hissettiği bir parçayı meydana getirmektedir. Gazete okunamazsa ve de televizyon izlenemezse dahi, kentsel ortama üstün gelen imgelemelerden kaçılamamakta. Bu yönden çağımızda meydana gelen kültürel değişim ve gelişmeler, siyasal sahada da reklâmcılıktaki yöntem ve tekniklerin kullanılmasına koşut bir muhit hazırlamıştır (Balcı, 2006).

Reklâm olgusuyla siyasî iletişimsellik anlayışı içeresinde iç içe bir ilişkisellik bulunmaktadır. Siyasî iletişimsellik anlayışıyla reklâm ilişkisi, hizmet ve ürünlerin tanıtılması amacıyla meydana getirilen ve topluluktaki bireyler üzerinde tutumların ve davranımların değişikliği meydana getiren reklâm olgusunun, yine bireylerin mutlak siyasî görüş ve düşüncelerinin onanması ve uygulanılmasını hedef edinen, ondada bu yönde tutum ve davranım değişikliği isteyen siyasî iletişimsellik anlayışıyla erek bakımından benzerliğiyle açıklamak imkan dahilindedir (Uztuğ, 2004).

Siyasî iletişimsellik anlayışında bireylerin kısa süre zarfında neticeye ulaşılmak istedikleri hâllerde, siyasî kampanyaların devirlerinde reklâmlarda kullanıla gelen yöntemler ve teknikler devam ettirilir. Bu devirde ilişkisellik o derece yakındır ki direkt reklâm modeli ile topluluğa mesaj verilmekte ve kısa süre içerisinde müspet neticeler beklenilmektedir. Siyasî kişiler içeresinde en kesif siyasî söylem ve eylemi olan siyasî parti ve liderlerin kendisini daha iyi tanıtması amacıyla reklâm ajansı ile çalıştıkları bilinmektedir. Küresel literatüründe siyasî reklâm olgusu, pek çok kişice öncelik edinilen yöntemler ve teknikler topluluğudur (Aziz, 2003).

Ülkemizdeyse siyasal reklâmcılık 1978'de Adalet Partisinin girişim ve teşvikiyle başlatılmıştır. Bu yönden 1978 senesi seçimleri siyasî iletişimseldik anlayışının geçmişi yönünden mühim bir devredir. Siyasî reklâmcılı̆̆ın bir diğer mühim kilometretaşı meşhur reklâmcı Senguela'nın 1991'de Anavatan Partisine reklâm kampanya ve gösterimi hazırlatmak amacı ile ülkemize 
gelmesidir. Bu seneden başlayarak ülkemizde siyasî iletişimsellik anlayışı uygulamaları değişik bir hız kazanmış ve siyasî reklâmcılığın 1991 senesiyle birlikte ehemmiyeti kesin şekilinde belirginleşmiştir. Siyasî partiler ve de adayların, geçmişte olduğundan farklı şekilde yalnızca afişler, bayraklar ve sloganlar temeline meydana getirilen siyasî kampanyalarla seçim kazanamayacaklarının dışında seçimleri kaybedecekleri kavranılmıştır ve bu seçimler ile birlikte, siyasî parti mensupları seçim kampanya ve gösterimin düzenlemek görevini uzman olan reklâmcılara bırakmıştır (Uztuğ, 2004).

\section{Siyasal İletişim ve Siyasal Pazarlama}

Siyasetin kendisi bir bilim dalı olarak çok uzamsal bir sahası kaplayan, sınırları kalıcı çizgiler ile çizilememiş ve boyuna değişim ve gelişim dahilinde olan bir bilim dalıdır. Pazarlamaysa iletişimsellik durumu gibi hayatımızın ayırılmaz bir parçasıdır ve farkında olunmayarak kendimizi dahilinde bulduğumuz toplumsal sahadır. Tüm sosyal bilimlerde olduğundan siyasî anlayışın da pazarlamanın da hususu insandır (İşler, 2007). Dolaysıyla siyasî iletişıimsellik anlayışının hedeflerine ulaşılmasında faydalandığı en mühim yöntem, teknik ve faaliyetlerden birisi de hiç kuşkusuz pazarlamadır.

Pazarlama yalnızca malların ve hizmetlerin değil de, ürünlerin, fikirlerin de hedeflenen kitleye yayılımı ve benimsetilmesi kolaylaştırmakta olan bir uygulama bütünüdür. Bu uygulama bütünü kar ereği amaçlayan kurum ve kuruluşlar şeklinde teşekküllerce değil, ereğine ulaşılmak isteyenlerce de, esasen siyasîler ve partilerce yürütülebilmektedir (Aktaş, 2004).

$\mathrm{Bu}$ manada siyasî iletişimsellik anlayışı, pazarlama tarzının olgu ve süreci ile de iç içedir. Pazarlamanın olgusu içerisindeki pek çok özelik siyasî iletişıimsellik anlayışında da görülmektedir. $\mathrm{Bu}$ ilişkisellik o kadar yakındır ki pazarlamanın bir türevi şeklinde siyasî pazarlamanın kavramsal bütünlüğü literatüre yerleştirilmiştir. Bir ürün, hizmetin pazarlanmasında ifadesini bulan özelikler, siyasî kişilerin darca ve genişçe manaları ile tüm söylemleri ve eylemleri için geçerlidir. Seçim zarfında bir partiye oy istenilmesi, önce parti programı, partinin diğer partilere nazaran farklılık ve farkındalıkları, adayların özeliklerinin seçmen kitlesine yeterince aktarımı ile imkanlıdır. İşte bu tür bir çabanın ismi siyasî pazarlamadır (Aziz, 2003).

Siyasî pazarlama, siyasî katılımda seçmen kitlesini bilgilendirebilmek suretiyle genişleyebilmek ve çokça bireye siyasî anlayışına katılım hissi kazandırmaktadır. Bu siyasî ilgililik düzeyi ülke 
problemlerine topluluğun sahip çıkabilmesini sağlamaktadır. Böylelikle siyasî yönetimi elde eden, icraatlarında bir ölçekte daha geniş kesimlerin olası tepkisini seçimden seçime değil de, kesiksiz şeklinde nazara alma ihtiyacı hissetmektedirler. Bu da, siyasî yönetim paylaşımını piramidin tepelerinden biraz daha aşağıya çekmiştir; yeni yeteneği ülkenin siyasî hayatına kazandırmıştır, şahsî sahalarında başarılı olan bireylerin bilgilerini ve tecrübelerini ülke probleminin analizinde kullanma suretiyle seviyeli ve randımanlı bir siyasal hayatın gelişimine destek bulunmuştur (Uztuğ, 2004).

Değişik siyasî problem ve bunların çözümleri hususunda yalnızca umumî bir bakış açısına haiz olan siyasetçi kişiler, siyasî pazarlama yardımı ile daha ayrıntılı ve teknik bilgiler edinmek ve yine siyasî pazarlama olgusunun yardımı ile bu bilgileri problem çözümünde teknik yöntem ve ilkelere dönüştürmektedir. Siyasî hayatta bir adayın genellik ile kabul görmüş siyasî özeliklere haiz bulunması esas koşuldur. Siyasî pazarlama olgusu adayın bu özeliklerinin seçmence anlaşılabilmesine yardımcı olabilirler. Bunların ötesindeyse siyasî pazarlamayla ilgili olgular, topluluktaki bir takım gurupların, ideoloji ve kabul görmüş fikirlerin dışlanmasını ketleyen bir vasıta şeklinde görülebilir (Tan, 2002).

\section{Siyasal İletişim ve Siyasal Retorik}

Siyasî iletişimsellik anlayışı inandırıcı nutuk şeklinde özetlenebilecek belâgat ile çok yakından ilişkilidir. Eski Yunan toplumunda birey ve toplulukların bu hususta inandırılması amacıyla meydana getirilen iletişim mefhumu, akıl ve mantığa koşut ikna edici söylem, veciz söylem şeklinde mukannen retorik konuşmak şeklinde yapılırdı (İşler, 2007). Şehir devletlerinin bulunduğu Atina'nın ve Sparta'nın ve bu gibi küçük ölçekli yönetimlerin hakim olduğu Eski Yunan toplumunda siyasî kişilerin halkı bilgilendirebilmesi; tutumlarında ve davranımlarında farklılaşmalar yapılmasını istediklerinde, vakit vakit halkı, agoralar namıyla isimlendirilen meydanlarda toplarlar ve onlara sözlü veya yüz yüze iletişimde bulunurlardı. Bu tür iletişimselliğin temelindeyse kabullendirici söylem bulunması gerekirdi. Bu ise retoriksel ifadenin mefhum olarak ehemmiyet arz etmesine sebebiyet vermiştir (Kalender, 2000).

Retorik, dinleyicilerin önünde meydana getirilen konuşmalarda, dilin ikna etme amaçlayan kanıt, kıyas kullanılmak suretiyle, vakit vakit mecazdan ve veciz ifade tarzlarından destek alarak kullanılmasidir (Habermas, 1997). 
Aristo çağlar öncesinde yazmış olduğu ve elimize yalnızca bir kesiminin ulaşmış olduğu kitabında, ağırlıklı şeklinde propagandalar, iknalar, retoriklerden söz etmiştir. Aristo, bireylerin kendileri arasında tartışır iken birbirlerini ikna etmekte faydalanabilecekleri bir bilgilenim sahasından söz etmiştir. Retorik, akla koşut bir dayanağı olmadan kişi kandırmak ilmi değildir, kişinin savunmakta olduğu düşünce ve görüşü yalın, net ve kuşkuya yer vermeyecek ölçekte kesinlik ile savunmasıdır. Böylelikle güçlülük, tutarlılık ve mantıklılık bir birliktelik hâlinde söze kudret vermektedir. (Habermas, 1997). Aristo, retorik konuşmalarını siyasî, hukukî ve ayinî şeklinde üçe ayırarak incelemiştir.

Siyasî iletişimsellik anlayışı uygulamasının gerçekleştirilme ve geliştirilme noktasında retorikler, varlığı ve gücüyle Eski Yunan toplumundan çağımıza dek siyasî iletişimsellik anlayışları mühim bir kıymet katmıştır. Genişçe halk kitlesini tesirlemek; onların içerisindeki tutumlar ve davranımlarda değişiklikler yaratmak suretiyle tercih ve eğilimlerine yol gösterme ve yön vermeye sağlamak için uygulanan iknayla ilgili yöntem ve teknikleri retoriklerin tesiriyle daha kalıcılık ve daha tesirlilik hâline gelmektedir.

Bundan ötürü siyasî iletişimsellik anlayışındaki retoriksel unsuru değişik bir önemde tutulmalıdır, retoriksel membalı çabalamaya çokça özen gösterilmelidir. Siyasî iletişimsellik anlayışının en mühim unsurları içerisinde yer edinen siyasî liderlerin retoriksel teknik ve yöntemleri bilmesi ve bunun sağladığı avantajdan faydalanması başarılarına katkı sağlayacaktır (Çavdar, 2004).

\section{Siyasal İletişim ve Siyasal Etik}

Etik, bireyin şahsî olarak kendisine ve diğer bireylerin benliklerine iyi davranması, iyiliğe varılabilmesi amacıyla kendisini uymaya mecburî gördüğü manevî ve ruhsal vazifeler ve bu vazifelere ilişkin kurallar bütünüdür (Özsoy, 2009). Etik bazen etikle ve adapta, bazen de adabı muaşeretle ifade edilmektedir. Etik ifadesinin Grekçe'de ethikosdan geldiği düşünülmektedir. Latince'de ethicius ifadesinin Türkçe'de karşılık bulduğu kavram da törebilimdir (Bülbül, 2002). Etik, ahlâk sahasında düşünmek, felsefe geliştirmek sürecinin bireye kazandırmış olduğu bir etkililiktir. Etiğin hususu ahlâktır ve etiğin sorunsalını ahlâkın açıklanması ve buna yönelik yöntem ve ilkelerin saptanılması meydana getirmektedir. Etik, ahlâkın mutlak surette bir disiplinle çözümlenebilmesinin ve bu çözümlenme neticesinde başkaca veriler özelinde sentezlere varılmak suretiyle ahlâksal bir tutarlılık ve de yaklaşım edinilmesi çabasıdır (Özsoy, 2009). 
Zaman içerisinde toplulukların git gide sayısal biçimde çoğalma, mekansal biçimde genişleme ile siyasî söylem ve eylemde bulunulan aktörlerin fazlalaşması siyasî iletişimsellik anlayışında etik hususunu meydana getirmiştir. Kısır ölçekli ve kalıplı siyasî söylemin, yöneten kişilerin halkça seçilmesiyle alakalı siyasî uygulamalardaki söylemleri dijital devremle şekillenen iletişim çağında çok ciddi ölçüde değişikliğe uğramıştır. Eski Yunan toplumundaki siyasî iletişimsellik anlayışı olgu ve sürecindeki içerikte ifadesini bulan teknikler ve yöntemler çağımızda bütünü ile değiş̧miş görülmektedir. Ancak, siyasî söylem ve eylemdeki etik hususu günümüzde daha da ehemmiyet kazanmıştır. Mevcut koşullara dek gelmiş olan kapsamlı kanıysa, siyasî söylem ve eylemlerin içerisinde olanların, seçimi kazanma, yönetici olma uğruna etik söylem ve eylemler içerisinde olmadıklarıdır (Sönmez, 2009).

Çağımızda algılandığı şekliyle ahlâk ve etik mefhumlarının birbirinin dahilinde, birbirinin yerine kullanıldığı kabulü, özelikle kısır manası ile yöneten kişilerin, kısaca bir devletin en ileri düzeyde yönetici olan kişileri şeklinde yasama meclisi, cumhurbaşkanı, yönetim sistemine bağlı bakanlar, bakanlar kurulu, başbakan, kraliçe, kral v.s. gibi ileri düzey yönetimlerde bulunan siyasî kişilerin; yaptığı işler, bu işlerin aktarılmasında etik kural ve kaidelere uymaları; kurumsal ve ferdî vazifelerin uygulanılmasında ahlâka koşut hareket etmeleri beklenir (Sönmez, 2009).

Siyasî iletişimsellik anlayışında etik hususunun iki değişik dayanak ve kaynağı bulunmaktadır. Bunlar, ilki, kanunî düzenleme ve uygulamalara yaslanan etiktir, ikincisi ise gelenek ve göreneklere yaslanan etiktir (Aziz, 2003). Bunlara kısaca şöyle değinebiliriz:

Kanunî Düzenlemelere Dayalı Etik: Bir topluluktaki etiksel kural ve kaidelerin ana dayanağı ve kaynağı, başlıca o ülkenin anayasası şeklinde; yasa, tüzük, yönetmelik ve diğer hukukî düzenleme ve uygulamalardır. Siyasî arenada var olan her kesin, her kurumun bu kural ve kaidelere uyması beklenir. Hakikatte ise bu kural ve kaidelere uymama esasen suçtur ve cezai müeyyide gerektirir (Aziz, 2003).

Gelenek ve Göreneklere Dayalı Etik: Siyasî arenadaki kişilerin siyasî iletişimsellik anlayışında bulunur iken, topluluktaki gelenek ve göreneklerin meydana getirdiği değerler ve ilkeler bütünü ile toplumsal değişimin neticesi topluluk dinamiklerinden türeyen etiksel kural ve kaidelere uymaları beklenir. Herhangi bir siyasî partinin, çalışma ve uygulamalarıyla alakalı abartılıca söylem ve eylemde bulunulması ve yerine getirilemeyecek vaatlerin verilişi, bu tarz davranımlara misal şeklinde verilebilir. Siyasî iletişimsellik anlayışında bulunulan kişiler, guruplar, kurumlar ve kuruluşların o toplulukta kalıcı, yazılı olmayan, toplulukça kabul edilmiş değer ve ilkelere; siyasî 
tümlükler, rejimler, millîyetçilikler, diller, dinler, etniklik ve 1rksallık, sancak, bayrak gibi hususlardan dayanağını ve kaynağını bulan hususlarda etik davranımlar beklenir (Aziz, 2003).

\section{Sonuç}

Siyasî iletişimsellik anlayışı ifadesinin ortaya çıkışı ve yer yüzündeki süratli gelişim seyri kitle iletişim araç ve gereçlerinin ilerleyiş sürati ile paralellik arz etmiştir. Dolaysıyla kitlesel iletişim yönteminin ve tekniğinin meydana çıktığı siyasî iletişimsellik anlayışı çabalamasında kitlesel iletişimle ilgili araç ve gereçlerin etkinliği mühim bir yer almaktadır. Kitlesel iletişimle ilgili araç ve gereçlerin kamuoyuna verdiği haberler ve bilgilerin topluluk içeresindeki bireyin siyasî tutumlarına ve davranımlarına etki göstermektedir. Kitlesel iletişimle ilgili araç ve gereçlerin söz konusu vazifesi siyasî iletişimsellik anlayışının amaç edindiği biçimde ortaya çıkmasına direkt olarak destek sunması yönünden önem arz etmektedir. Dolaysıyla kitlesel iletişimle ilgili araç ve gereçlerin toplumsal işlev yapılarından birisi olan bilgilerin ve haberlerin paylaşımı, siyasî anlayışa yönelik bilgiler ve haberlerin paylaşımı şeklinde de nitelendirilmektedir.

Siyasî iletişimsellik anlayışı bireyin yaşamına kuramdan önce faaliyetlerle girmiştir. Özelikle 2. Dünya Savaşı'nın sonrasında devletlerin ve siyasî yönetimlerin değişen ve dönüşen rejimi ve radyoları, televizyonlar gibi kitlesel iletişimle ilgili araç ve gereçlerin yetkin biçimde birey hayatına sokulması siyasî iletişimsellik anlayışının uluslararası kamuoyunda kendisine has yer edinmesine de imkan tanımıştır.

Siyasî iletişimsellik anlayışı sürecinde televizyonun, son elli senede onunla ilişkisel olan kuşak ve çağlara kendi kültürünü öğretmiştir; siyasî rejim iletişim yönetimi çerçevesinde televizyona ve diğer kitlesel iletişimle ilgili araç ve gereçlere öncelik vermek suretiyle yayımcılık sahasını biçimlendirmiştir. Siyasî mücadelelerse daha ziyade televizyonlar üzerinden sürdürülmüştür. Benzeri bir şekilde, bu koşullar altında siyasî iletişimsellik anlayışının ayırılmaz bir yönü olan özgür ilke ve değerlerin imkanları siyasî iletişimsellik anlayışı süreçlerinde televizyon ve diğer kitlesel iletişimle ilgili araç ve gereçlerin belirlediği çerçeveler içerisinde gerçekleştirilmiştir. Ancak bir çok iletişim kuramcısı ve bilim insanının son üç yüz yıldır geçerliliği olan sanayi devrimi ve bunun sonrasında oluşan sanayi medeniyeti ve topluluğundan sonra, içerisinde bulunulan yirmi birinci yüz yılda yeni bir medeniyet ve yapısal toplumsal durum devreye girildiğine yönelik eğilimlerine fikir oluşturan dijital iletişim tekniği ve yöntemi, kendisini takibi 
son derece güç bir sürat ile sürekli yenilemek suretiyle siyasî iletişimsellik anlayışı süreçlerini geliştirmektedir.

Yeni iletişim tekniği ve yöntemi siyasî kişiliklerin hedef edindiği kitlelerle iletişim kurmak biçimlerini etkilemiştir, her bir kitlesel iletişimle ilgili araç ve gereçlerin teknik ve yöntemi bir önceki iletişimsel yapı dayanaklarını dönüştürmek sureti ile yeni iletişim biçimleri yaratarak var olan siyasî ve içtimaî ilişki, kuram ve yöntemlerin yeniden biçimlendirilmesine katkı sunmuştur. Demokrasi ikliminin sağladığı özgür ilke ve değerler atmosferinde gelişmekte olan karşılıklı etkileşimler, teknolojik ilerlemeler paralelinde çok daha fazda liberal eğilimleri beraberinde getirmektedir. Profesyonel kişilerce, bir dijitalleşme ve etkileşim teknik ve yöntemi şeklinde gelişen internet teknolojisi ve yönteminin bireylerin sürece direkt katılmasına imkan sağlamasıyla liberal anlayışa dönük ilkeler yaygınlaştırmakta olduğu, temsilî demokrasi yönteminden aracı olanların giderilmesi ve tamamen ortadan kaldırılmasıyla Eski Yunan'da, özelikle Atina'daki geçmiş özgürlük ilkelerine yönelik bir gidişatla olanak tanıyacağı görüşü günbegün çok daha gür bir ses ile dillendirilmektedir.

Ayrıca son olarak internet, siyasî aktörlerin başındaki siyasî partiler ve adaylarına, vatandaşlara ve toplumun en kılcal damarlarına dek geleneksel medyanın (elektronik ve yazılı medyanın) olumsuz bir biçimde değerlendirilen manipülatifçe faaliyetini izale etme imkanını tanımaktadır.

\section{Kaynakça}

Arıcan, M. Z. (2004). Etkili Aday Fotoğrafı ve Çekim Süreci. F. Uztuğ (Ed.). Siyasal İletişim Yönetimi. İstanbul: Mediacat Kitapları.

Arık, C. (2000). Siyasal İkna. Ankara: Vadi Yayıncılık.

Aristo, Retorik. Mehmet H. D. (Çev.). Yapı Kredi Yayıncılık, Cogito, İstanbul, 1995.

Atabek Ü. (2001). İletişim ve Teknoloji: Yeni İmkanlar Yeni Pıroblemler. Ankara: Seçkin Yayıncilik.

Aydın, N. (2009). Etkili İletişim Taktikleri. İstanbul: Kum Saati Dağıtım.

Aziz, A. (2003). Siyasal İletişim. Ankara: Nobel Dağııım.

Bakan Ö. (2007). Siyasî Partilerin İnternet Sitelerinde Anket Kullanılması. İzmir: Uluslararası Medya ve Siyaset Sempozyumu, Ege Üniversitesi İletişim Fakültesi.

Bektaş, A. (2002). Siyasal Propaganda. İstanbul: Bağlam Yayıncılık. 
Bilgin L. (2008). Müspet İmaj Yaratmak: Halkla İlişkiler. İstanbul: Kum Saati Yayıncılık. Bülbül A. R. (2000). Halkla İlişkiler ve Tanıtım. Ankara: Nobel Yayıncılık.

Çakan, I. (2004). Konuşunuz Konuşturunuz, Tek Parti Devrinde Politikalarının Etkili Silahı: Söz. İstanbul: Otopsi Yayıncılık.

Doğu B. (2007). Türkiye'deki Siyasal Parti İnternet Sitelerinin Gençlere Dönük Enformasyonlarının Değerlendirilmesi. İzmir: Uluslararası Medya ve Siyaset Sempozyumu, Ege Üniversitesi İletişim Fakültesi.

Eco U. (2001). Açık Yapıt. Savaş, Pınar (Çev.). İstanbul: Can Yayıncılık.

Erdoğan İ. ve Korkmaz, A. (2005). Öteki Kuram. Ankara: Erk Yayıncılık.

Ersoy A. B. (2007). e-Devlet ve İletişim Teknolojileri İlişkisi: Panel Eştümleşim Analizi Denemesi. İzmir: Uluslararası Medya ve Siyaset Sempozyumu, Ege Üniversitesi İletişim Fakültesi.

Geray H. (2003). İletişim ve Teknoloji Uluslararası Birikim Düzeninde Yeni Medya Politikaları. Ankara: Ütopya Yayıncılık.

Gerbner, G. (2005). Kitle İletişim Araç-Gereçleri ve İletişim Kuramı. Ankara: Ütopya Yayıncılık. Gürüz D. ve Ana A. (2005). İletişime Yeni Yaklaşımlar. Ankara: Nobel Dağıtım.

Işık, M. ve Erdem A. (2008). Medya ve İletişim. Konya: Eğitim Kitabevi.

İlal, E. (1989), İletişim, Yığınsal İletim Araç-Gereçleri ve Toplum, İstanbul: Der Yayıncılık.

İşler, E. K. (2007). Demokrat Parti'nin Halkla İlişkileri Üzerine İnceleme. İletişim Kuramı ve Araştırmaları Dergisi, S: 12 (24), s. 111-128.

Kalender A. (2000). Siyasî İletişim ve İkna Süreçleri. Konya: Çizgi Yayıncılık.

Kaya, A. R. (1985). Kitle İletişim Sistemleri, Ankara: Erk Yayıncılık.

Kentel, F. (2000). Demokrasi Kamuoyu ve İletişime Dair. Birikim Dergisi, S: 30, s. 39-47.

Köklün, B. (2008). Çalışan Kişilerin Performansını Arttırmada Bir Araç Motivasyon ve Motivasyon Teknikleri. Ankara: Atılım Üniversitesi, Sosyal Bilimler Enstitüsü, Yüksek Lisans Tezi.

Kuş, E. (2009). Nicel Nitel Araştırma Teknikleri. Ankara: Anı Yayıncılık.

Küçükkurt M. ve Can B. (1988). İletişimde Kaynak Etkisi ve İkna Katkısı. İzmir: EÜBYYO Yayıncilik.

Marie, C. J., Claude, E. (1995) Seçim Sistemleri. Kotil, A. (Çev.). İstanbul: İletişim Yayıncılık. Mattelart, A. M. (2006). İletişim Kuramları Tarihi. İstanbul: İletişim Yayıncılık. 
Mc Quail, D. (1994). Kitle İletişim Kuramı. Yüksel, A. H. (Çev.). İstanbul: İletişim Yayıncılık. Mutlu E. (2005). Kitle İletişim Kuramları. Ankara: Ütopya Yayıncılık.

Öksüz O. ve Yıldız E. (2004). Siyasal İletişimde İnternet Kullanılması: Türkiye ve ABD’deki Siyasal Partilerin internet Sitelerinin Karşılaştırmalı Analizi. İstanbul: İstanbul Üniversitesi İletişim Fakültesi Yayınları.

Özüpek, M. N., Altunbaş, H. ve Aktaş, H. (2007). Seçim Kampanyaları ve İnternet/Seçim Kampanyalarında Partilerin İnternet Siteleri. İzmir: Uluslararası Medya ve Siyaset Sempozyumu, Ege Üniversitesi İletişim Fakültesi.

Sağnak M. (1996). Medya-Politik. İstanbul: Eti Kitapları.

Silah, M. (2000). Sosyal Psikoloji (Davranışsal Bilimler). Ankara: Gazi Kitabevi.

Şener, G. (2007). Yeni Bir Sol Kimliğin İnşasında İnternetin Rolü. İzmir: Uluslararası Medya ve Siyaset Sempozyumu, Ege Üniversitesi İletişim Fakültesi.

Timisi, N. (2003). İletişim Teknolojileri ve Demokrasi. Ankara: Dost Kitabevi.

Tokgöz O. (2004). Siyasal İletişimi Anlamak. Ankara: İmge Kitabevi.

Topuz H. (2004). Siyasal Reklâmcilık: Dünyadan ve Türkiye'den Örneklerle, İstanbul: Cem Yayıncilik.

Tuncel H. S. (2005). Yeni İletişim Teknolojilerinde Yerel Medya. Yeni İletişim Teknolojileri ve Medya. Alankuş S. İstanbul: İPS İletişim Vakfı Yayıncılık.

Uluç G. (2003). Küreselleșen Medya: İktidar ve Mücadele Alanı. İstanbul: Anahtar Kitaplar.

Uslu, Z. K. (2000). Sihirli Değnek Çağdaş İllüzyon Dilemması, Siyasal İletişim. Ankara: 1. Uluslararası İletişim Sempozyumu Bildiri Kitabı.

Vural Z. B. ve Bat M. (2007). Siyasal İletişim Sürecinde Yeni Teknolojiler: Siyasî Partilerin İnternet Sitesine Dönük Bir Analiz. İzmir: Uluslararası Medya ve Siyaset Sempozyumu, Ege Üniversitesi İletişim Fakültesi. 